\title{
The development of Brazilian agriculture: future technological challenges and opportunities
}

\author{
Pedro A Arraes Pereira', Geraldo B Martha $\mathrm{Jr}^{2^{*}}$, Carlos AM Santana ${ }^{3}$ and Eliseu Alves ${ }^{4}$
}

\begin{abstract}
Ensuring food security for the world's population over the coming decades will face the challenges of a larger world population, greater urbanization, limited natural resources, higher levels of income, and stronger links between the agricultural and biofuel markets. Overcoming the challenges these represent will require, among other efforts, promoting sustainable expansion of agricultural production through higher productivity and greater cropping intensity. In this paper, we examine the role of Brazil's agriculture industry in the domestic and world markets; first, we review the country's agricultural development experience, and second, we address some key issues that will play a pivotal role in Brazilian agriculture in the future. The paper highlights the main aspects of the modernization process experienced by Brazil's national agriculture industry, presents the style of agricultural growth followed by the country, and discusses selected technologies that have played a major role in transforming the sector over the past four decades. We also analyze income from different farm sizes, and provide an overview of key agricultural research challenges and technologies that will be pursued by Brazil in the near future.
\end{abstract}

Keywords: Food security, Perspectives, Agricultural development, Brazil, Technology

\section{Review}

Ensuring food security has always been a priority issue for governments, international organizations, and society in general. Recent developments have further increased the political, professional, and public concern about this issue worldwide. After remaining at historically low levels for decades, nominal food prices have become substantially higher and more volatile since the 2007 to 2008 food crisis. Between January 2007 and June 2008, food prices increased significantly, ranging from $38 \%$ for sugar to $224 \%$ for rice [1]. Prices for other major food crops such as maize and wheat also experienced sharp spikes in the same period. Following this period of steep rises, the prices of these and other agricultural commodities experienced a downturn in the second half of 2008.

From the second half of 2010, food prices increased again, and peaked in January 2011. Through the course of 2011, a downward trend was re-established, but prices are still at historically high levels (Figure 1). Depending on how world production evolves in the next years,

\footnotetext{
*Correspondence: geraldo.martha@embrapa.br

${ }^{2}$ Embrapa Studies and Training, National Council for Scientific and

Technological Development (CNPq) fellow, Brasília, Brazil

Full list of author information is available at the end of the article
}

nominal food prices could remain at or even above the 1997 to 2006 level [2,3].

The consequences of higher prices and volatility in food markets are well documented in the literature, and include economic and political instability as well as cycles of positive and negative effects on consumers and producers. At high prices, increased poverty and malnutrition among the poor can be expected, but this trend for higher prices may also enhance investments in agricultural activities [4]. With increased supply, food prices decrease, benefiting consumers; however, excessive volatility may discourage longer-term investment in agriculture, and hence jeopardize an expansion in agricultural supply.

The degree of future volatility in the food system is uncertain. Therefore, efforts are needed to minimize high levels of volatility in global food markets and ensure food security for all. The nature of this challenge requires country-level actions on several fronts, including promoting a sustainable expansion of food production through increased levels of agricultural productivity and greater cropping intensity. Similar efforts will be needed to feed the world population over the coming decades with the substantially larger number of inhabitants predicted

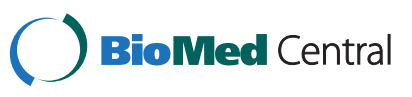




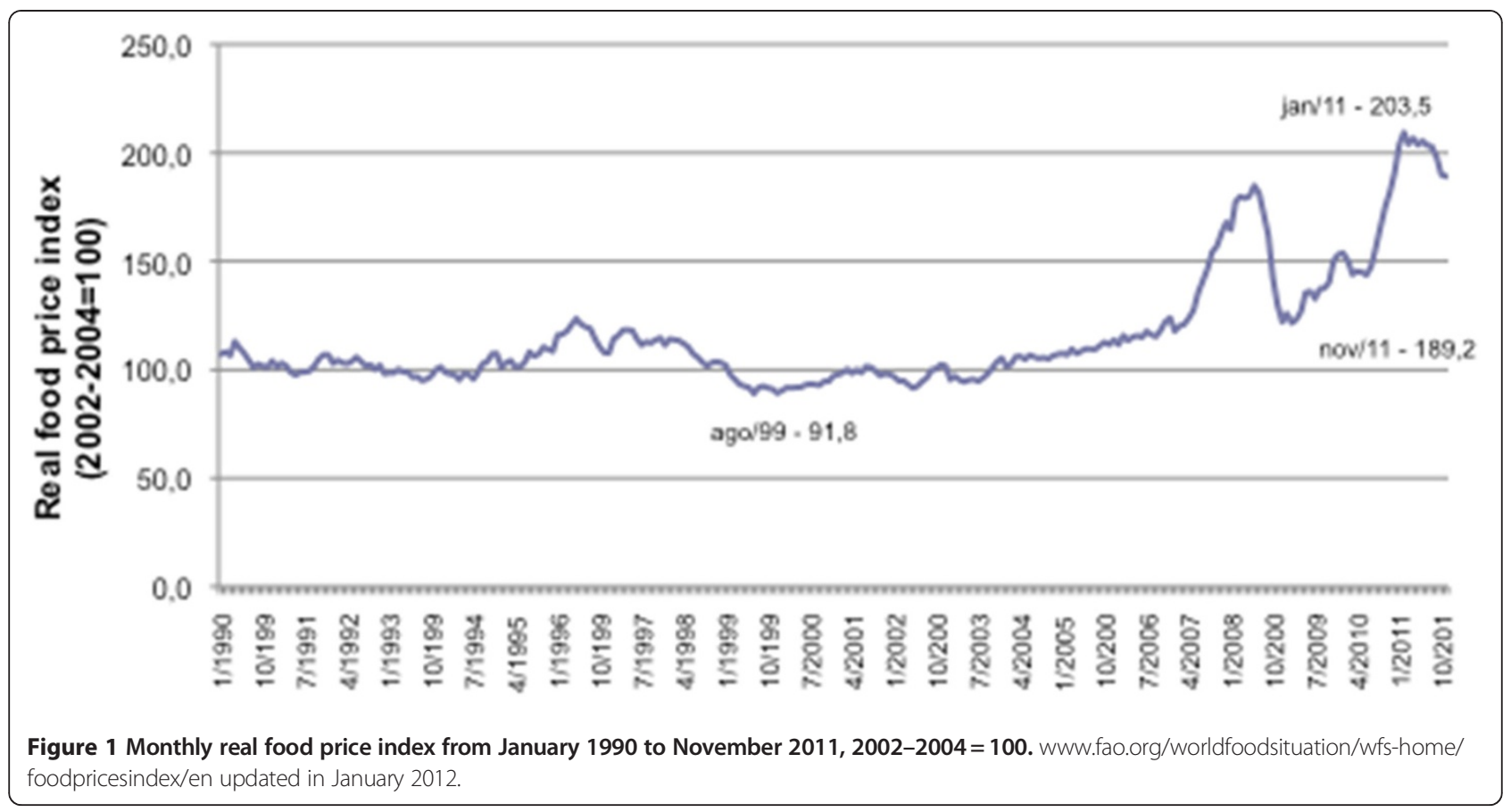

(2.3 billion people above the current level [5]), strong pressure on natural resources, greater urbanization, higher levels of income, and a stronger link between agricultural and biofuel markets.

Brazil is globally important for both food security and environmental sustainability. It is one of the three largest producers and exporters of sugar, coffee, orange juice, soybean, beef, tobacco, ethanol, and broiler chicken in the world. It has one of the largest biodiversity reserves in the globe, and a great number of farmers with strong entrepreneurial capability [4]. Moreover, it provides vital environmental services to the world and has a large availability of land and water, containing $13.5 \%$ of the world's equivalent potential arable land [6] and 15.2\% of the world's renewable water resources [7].

The country is notable for the science-based development of successful tropical agriculture. Tropical agriculture occurs between latitudes $23^{\circ} \mathrm{N}$ and $23^{\circ} \mathrm{S}$, generally in acid, weathered, tropical soils of low fertility. Until Brazilian agricultural researchers and partners developed new crops and forage varieties with agricultural practices tailored for tropical agriculture to create a modern and strongly competitive agriculture in Brazil (a 'new environment of commercial production') it was believed that only temperate regions could effectively and efficiently feed the world. For instance, the research and entrepreneurial efforts have been made in Brazil to develop and cultivate soybean varieties for lower latitudes, which are capable of producing yields as high (and maybe even higher) as those produced in temperate regions. In conjunction with this genetic effort, it was necessary to adopt new technologies intensively, such as novel agricultural practices and modern innovations, including improved seeds, fertilizers, and agrochemicals, to change the farming environment into a productive one.

It would, of course, be naive to think that agronomic decisions represent the core of the decision-making process. In fact, policy and economic pressures and incentives are often the determining factors behind decision-making by farmers.

In this far-reaching context, the story of Brazilian agriculture has generated intense interest from other developing countries, mainly in Africa, Latin America, and the Caribbean. Countries in these regions want to benefit from the way in which Brazil has transformed its agriculture into one of the most competitive in the world within the relatively short period of one generation [8]. Moreover, given future societal demands and climate change challenges, Brazil's experience in producing agricultural commodities in warmer climates and its rapid achievements using 'low-carbon agricultural technologies' have promoted strong interest from a broad (economic, social, and environmental) perspective.

The overall aims of this paper are twofold: first, to review Brazil's agricultural development experience in the period 1970 to 2010, and second, to provide a prospective view of the growth in this sector over the next two decades. More specifically, the aims are to: highlight the main aspects of the modernization process experienced by Brazil's national agriculture; analyze the resulting performance of the sector during the 1950 to 2010 period, focusing on the past four decades; highlight some features of the national agricultural 
research system and selected technologies; and present some future prospects for Brazilian agriculture.

\section{The development of Brazilian agriculture}

The strategic importance of the agricultural sector to Brazilian economic growth has been clear since the first colonial ventures in the early 16th century [9]. Until the 1930s, the Brazilian economy was strongly based on agricultural products destined for foreign markets, and two main classes of product (coffee and some other agricultural commodities (rubber, cocoa, cotton)) accounted for over 55\% of the exports until the 1960s [10]. These externally oriented expansions, focused on a few products, were eventually translated into short-lived periods of 'boom and bust' [9], leading to high volatility in economic growth (compared with developed countries) and to considerable external vulnerability [11]. By the end of the 1990s, commodities were still important for Brazilian exports, but the two main products of the 1990s, soybean and iron ore, represented $10 \%$ of total exports [10].

Ironically, in spite of the role of agriculture in the Brazilian economy, the country systematically received food aid from abroad until the 1960s, and even up to the 1980s, Brazil was still a large food importer. The traditional agriculture that prevailed in Brazil until the 1970s, whose growth mostly occurred on the extensive margin [9], was progressively transformed during the following decades into a modern and strongly competitive agriculture based on science [8].

To a great extent, these huge changes in Brazilian agriculture occurred in response to a strong demand, prompted by the government-led industrialization process that took place in Brazil from the 1960s to the early 1980s. This industrialization period was associated with a growing population with higher income and to a rapid process of urbanization. The increased opportunity cost of labor for farmers and extensive migration from rural areas to cities additionally led to a favorable environment for agricultural growth and modernization [12].

The ambitious industrialization policy aimed at reducing imports was based on exchange controls, on multiple exchange-rate systems to favor import of capital goods, and on subsidized interest rates for loans for the capital goods industry $[9,11,12]$. Along with the associated structural transformation that took place in the primary production sector, the industry and service sectors directly linked to agriculture, given their high backward and forward linkages, became two of the world's largest and most competitive industries.

Economic policy also promoted import of consumer goods and investments in energy and transport infrastructure. Investments in federal and state highway systems were key to agriculture expansion, initially in terms of area (from the 1950s to 1970s), and then in terms of increased productivity (transport of modern inputs and agricultural products to markets in the cities).

At that time of government-led industrialization, agricultural policies were subordinate to the major goal of industrialization [9]. Government priorities were being focused on cities. The purchasing power of urban salaries was further favored by investments in urban infrastructure, such as housing and health, and by safeguarding of salaries. Food prices were kept artificially low to avoid pressure on urban salaries. In addition to the expansion of agricultural output, agricultural exports were diversified, increasingly providing a means of capital goods imports for the rising national industry [8].

Economically, the industrialization policies were translated into an increase in the share of industry's gross domestic product (GDP) in the country's GDP (Figure 2). Politically, the industrialization policy shifted the power from the rural areas to the cities, transforming Brazil into a progressive urban society [13].

An outstanding effect of these distorting policies to the detriment of rural areas was an accelerated migration process from rural to urban areas, starting in the 1950s. The rural population of Brazil decreased from $64 \%$ of the total number of inhabitants in 1950 to $32 \%$ in 1980 and $16 \%$ in 2010 (Table 1).

After the 1990s, the urbanization process lost impetus. That was partly because the rural-urban cycle was almost completed in the south, southeast and midwestern regions of the country [14], but also because of the low economic growth rates during the 1980s and the 1990s, which possibly weakened the attractiveness of cities [8].

In summary, the rapid industrialization process that took place in Brazil between the 1960s and 1980s led to an important transformation in the country, which imposed pressures on the agricultural sector. The advantages granted to industrialization that discriminated against agriculture required, among other things, that food prices were kept artificially low to avoid wage inflation through pressure on urban salaries. In addition, migration from rural to urban areas was fuelled by better wages in the cities, a consequence of the growing industrialization that was taking place in the country. Political power also shifted from the rural areas to the cities. As a result, opportunities for agribusiness exports were identified as a means to generate funds to finance imports of technology and capital assets for the emerging industrial sector.

However, in spite of these pressures on the agricultural sector, it became clear that opportunities for agricultural expansion in traditional areas were limited. This scenario required a strategy to transform traditional agriculture into a modern, vigorous, and dynamic sector, based on scientific advances. Thus, it became clear that there was a need not only to increase productivity in already opened areas 


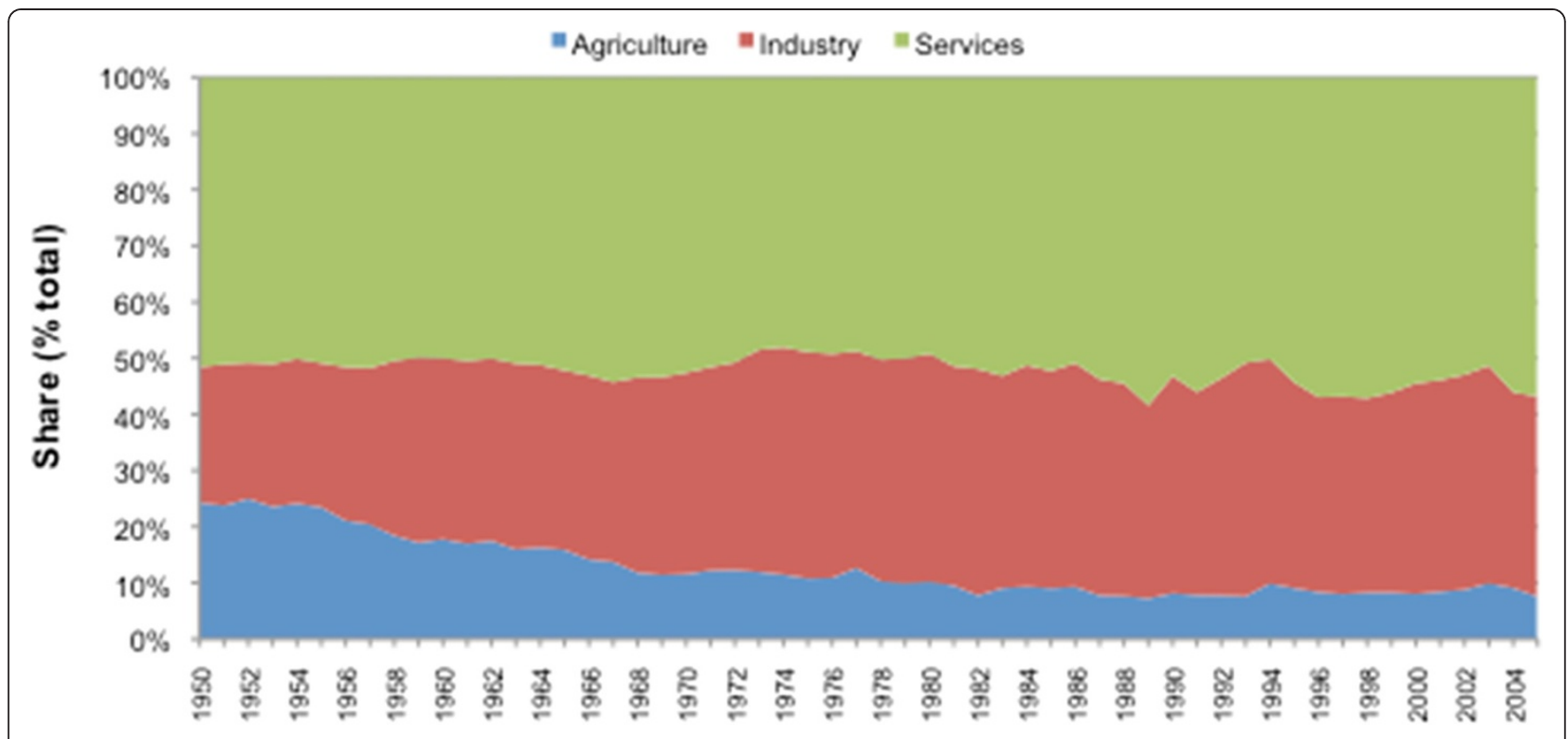

Figure 2 Sectoral distribution of gross domestic product (GDP) in Brazil, 1950 to 2005. Source: data from IBGE, elaborated by Baer [9].

but also to transform the "unproductive" Cerrado (the savannah-like biome in Brazil) into productive land in order to guarantee increased agricultural production and to ensure food for the growing urban population at affordable prices.

Three policies played a central role in the process of agricultural modernization: 1) the availability of subsidized financial credit, mainly for capital financing and for purchasing modern inputs; 2) the rural extension; and 3) the provision of support for agricultural research (the National Agricultural Research System, coordinated by the Brazilian Agricultural Research Corporation (Empresa Brasileira de Pesquisa Agropecuária; Embrapa)).

Embrapa is a case of successful institutional innovation. It is a public corporation model of organization, spatially decentralized but operating at national level, with specialized research units that invest in the professional development of its personnel (training and remuneration of

\begin{tabular}{|c|c|c|c|c|c|c|c|}
\hline \multirow[t]{2}{*}{ Region } & \multicolumn{7}{|l|}{ Year } \\
\hline & 1950 & 1960 & 1970 & 1980 & 1991 & 2000 & 2010 \\
\hline North & 70 & 65 & 57 & 50 & 42 & 30 & 27 \\
\hline Northeast & 74 & 66 & 58 & 49 & 39 & 31 & 27 \\
\hline Center-West & 74 & 63 & 49 & 29 & 19 & 13 & 11 \\
\hline Southeast & 52 & 43 & 27 & 17 & 12 & 10 & 7 \\
\hline South & 71 & 62 & 55 & 37 & 26 & 19 & 15 \\
\hline Brazil & 64 & 55 & 44 & 32 & 25 & 19 & 16 \\
\hline
\end{tabular}

Source: Data from IBGE, E. Alves calculations. human resources) and promote a vision of agriculture based on science and technology. Moreover, from the beginning, the organization has always been result-oriented. Embrapa was founded on two basic tenets: 1) a focused research model, concentrating on products and areas of fundamental importance for the development of the country, and constituting an objective way of identifying research priorities; and 2) development of its human resource capacity, based on strong training programs in centers of excellence around the world $[8,15]$.

From the mid-1990s onwards, macroeconomic stability, better relative prices for agricultural commodities in the world markets, and the maturation of tropical agricultural technologies that had been generated in the preceding two decades provided the basis for a new era in Brazilian agribusiness. The sector moved forward rapidly from a traditionally based agricultural system to one based on science.

As a result, between December 1977 and January 2007, the domestic price for food in Brazil, in real terms, dropped at a monthly average rate of $2 \%$ [16]. In fact, the price of a representative food basket in November 2011 represented, in real terms, around $50 \%$ of the price paid by consumers in January 1975 (Figure 3).

During a period of 36 years, food prices for consumers decreased by half, which greatly reflected the expansion of agricultural production in Brazil. Even when food prices peaked in 2008, it had a very small effect on the prices paid by consumers [17].

\section{The style of growth of Brazilian agriculture}

The expansion in supply for key agricultural commodities was very successful. In the 1976-2011 period, the 


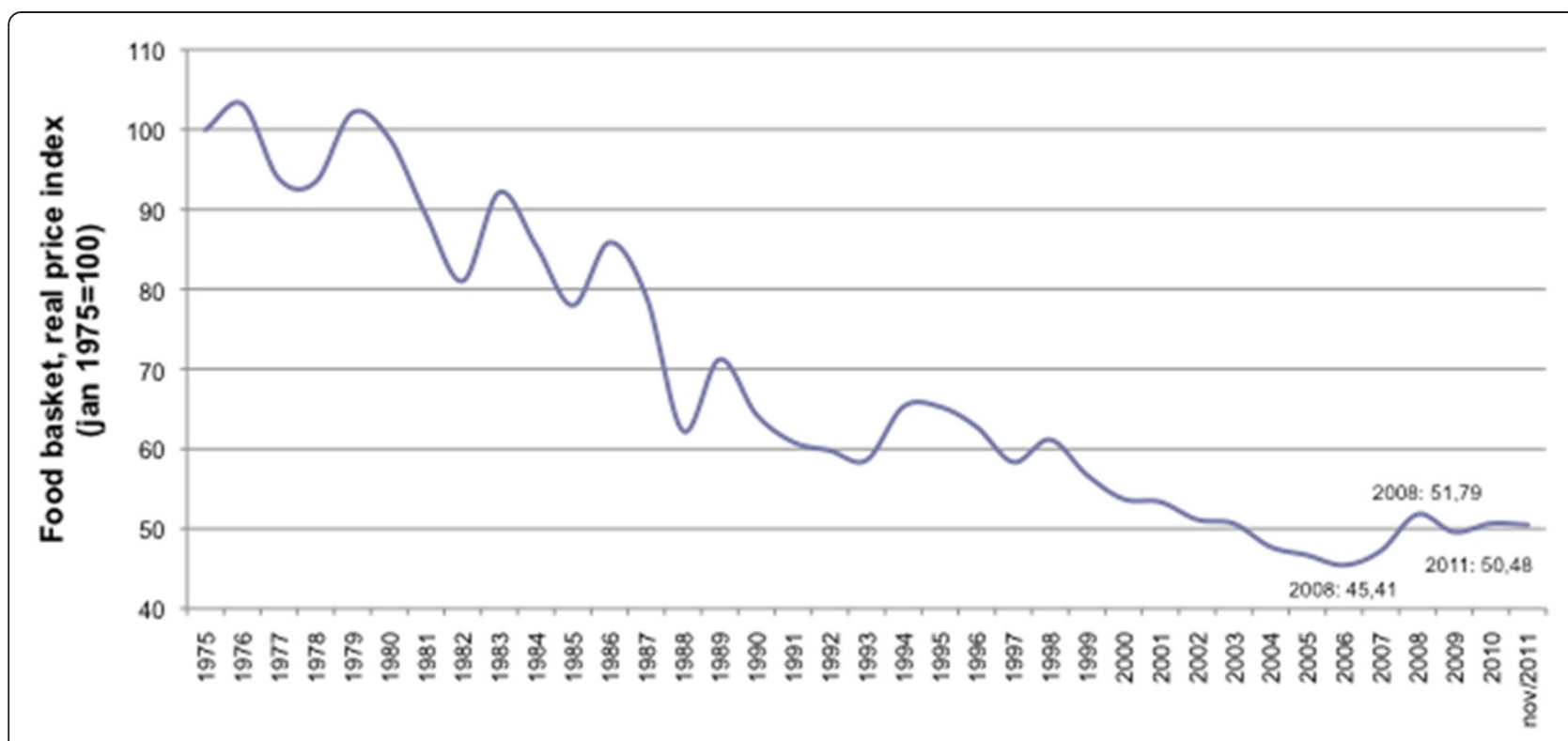

Figure 3 Monthly real food price index from January/1975 to November/2011, $\mathbf{1 9 7 5}=\mathbf{1 0 0}$. Source: Dieese database (2012), elaborated by Martha et al [17].

Brazilian grain and oilseeds area increased 32\% whilst production increased $240 \%$ and yields increased 2.57 times (Figure 4, Table 2). There was strong expansion in sugarcane production between 1975/1976 and 2009/ 2010, from 89 million to 696 million metric tonnes. In the same period, sugar production increased by $369 \%$, from 6.72 million to 31.51 million tonnes. Total ethanol production (including both anhydrous and hydrated ethanol) grew from 0.60 billion liters in 1975 to 1976 , to 25.56 billion liters in 2009/2010 (Figure 5).

Similar trends were seen in the meat sector (Figure 6). Beef, pork, and poultry production increased steadily, from 4.27 million metric tonnes in 1978 , to 25.496 million metric tonnes, in 2010/2011.

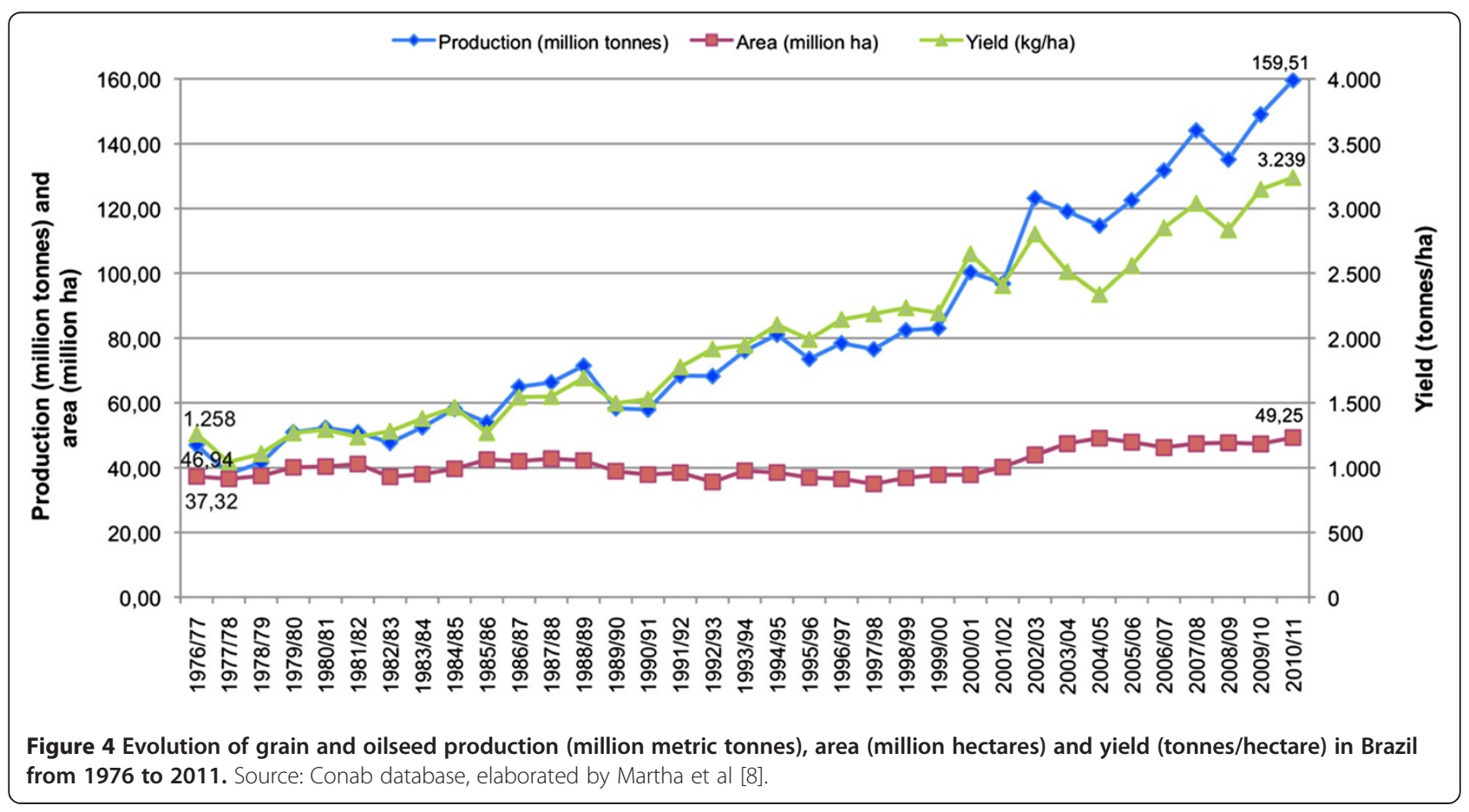


Table 2 Production, area and productivity annual growth rates in Brazilian agriculture, 1975 to 2010

\begin{tabular}{llllll}
\hline Years & \multicolumn{1}{l}{ Crop } & & & & \\
\cline { 2 - 6 } & Rice & Maize & Beans & Soybeans & Wheat \\
\hline Harvested Area & & & & & \\
1975 to 2010 & -2.38 & 0.38 & -0.64 & 3.58 & -1.63 \\
1980 to 1989 & -0.97 & 1.72 & 1.35 & 3.35 & 5.08 \\
1990 to 1999 & -3.25 & -0.95 & -3.04 & 2.66 & -6.15 \\
2000 to 2010 & -2.07 & 1.53 & 0.13 & 5.05 & 3.09 \\
Production & & & & & \\
1975 to 2010 & 1.05 & 3.43 & 1.52 & 5.55 & 1.35 \\
1980 to 1989 & 2.98 & 2.98 & 1.13 & 4.16 & 14.76 \\
1990 to 1999 & 0.82 & 3.54 & 0.28 & 6.80 & -2.09 \\
2000 to 2010 & 1.31 & 4.38 & 2.63 & 6.06 & 5.96 \\
Productivity & & & & & \\
1975 to 2010 & 3.51 & 3.04 & 2.18 & 1.90 & 2.92 \\
1980 to 1989 & 3.99 & 1.24 & -0.22 & 0.79 & 9.21 \\
1990 to 1999 & 4.20 & 4.53 & 3.43 & 4.04 & 4.32 \\
2000 to 2010 & 3.45 & 2.80 & 2.50 & 0.96 & 1.79 \\
\hline Source: Conab and IBGE databases, elaborated by Contini et al [20]. &
\end{tabular}

Source: Conab and IBGE databases, elaborated by Contini et al [20].

In the period covering 1978 to 2011, poultry production increased from 1.096 million tonnes to 12.928 million tonnes; pork production increased from 1.060 million tonnes to 3.384 million tonnes; and beef production increased from 2.114 million tonnes to 9.184 million tonnes. During the same period, yearly growth rates recorded for beef, poultry, and pork were, respectively,
$4.70 \%, 8.02 \%$, and $3.70 \%$. Milk production also increased markedly, from 11.16 billion liters in 1980 to 30.3 billion liters in 2009.

Another important characteristic of the expansion of production in Brazilian agriculture was its focus on productivity gains. During the period 1950 to 2006, productivity gains accounted for $79 \%$ of the growth in beef production in Brazil and supported a land-saving effect equivalent to 525 million hectares. Therefore, without this land-saving effect, an additional pasture area 25\% larger than the Amazon biome in Brazil would have been needed to meet 2006 levels of Brazilian beef production [18]. During this same period, production of Brazilian grain, oilseeds, and sugarcane provided an additional land-saving effect of 78 million hectares [39].

The total factor productivity (TFP) for Brazilian agriculture increased steadily over the 36 years from 1970 to 2006. Compared with 1970 (index 100), TFP increased by $124 \%$, production rose by $243 \%$, and inputs grew by $53 \%$. Gains in productivity represented $65 \%$ of agricultural output in the period 1970 to 2006, and inputs accounted for $35 \%$ [19].

\section{Agricultural productive capacity (with a special focus on technologies)}

The three major determinants of agricultural productive capacity are human capital, technology generation and dissemination, and adequacy of natural resources and weather conditions [17].

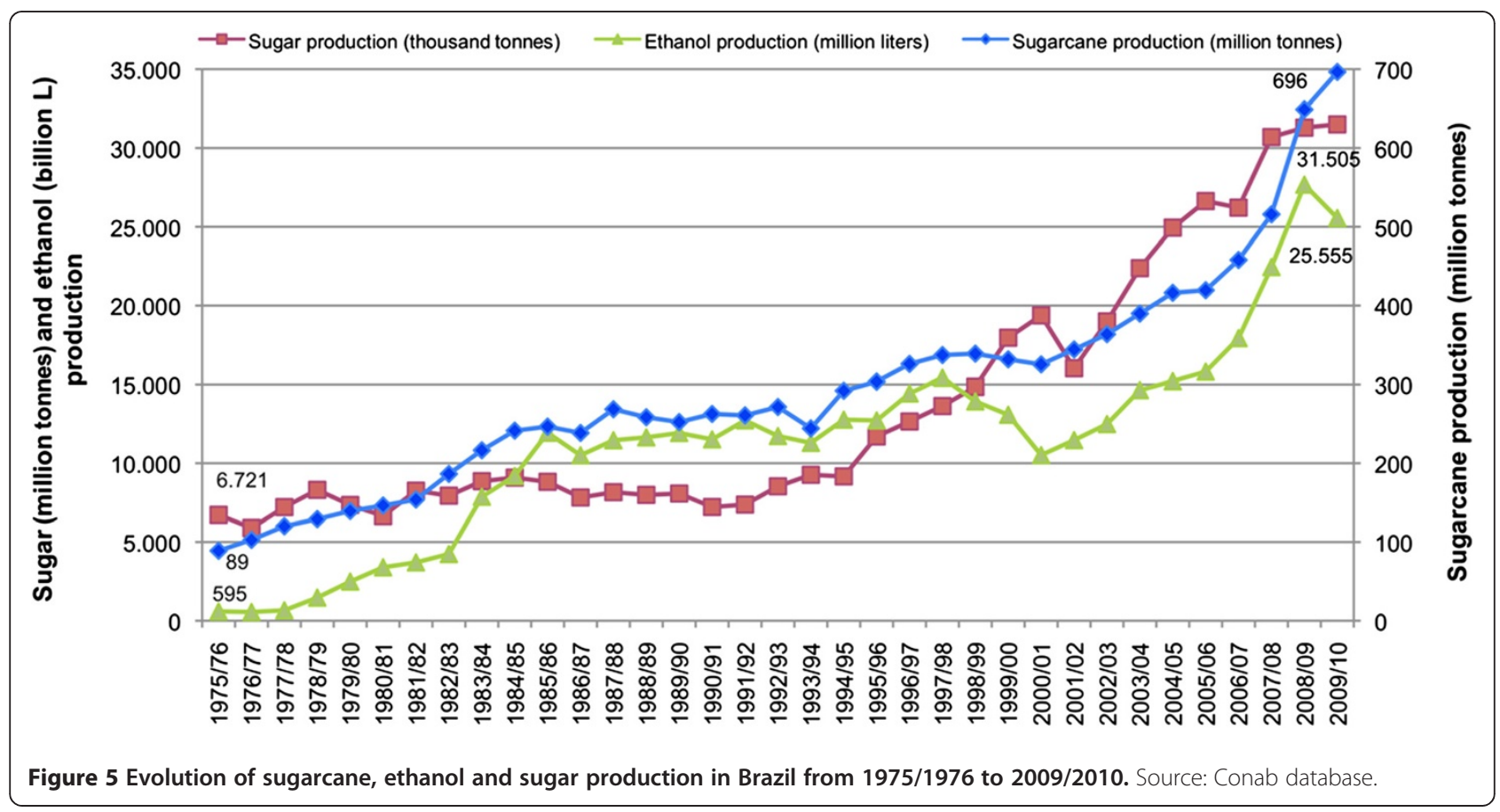




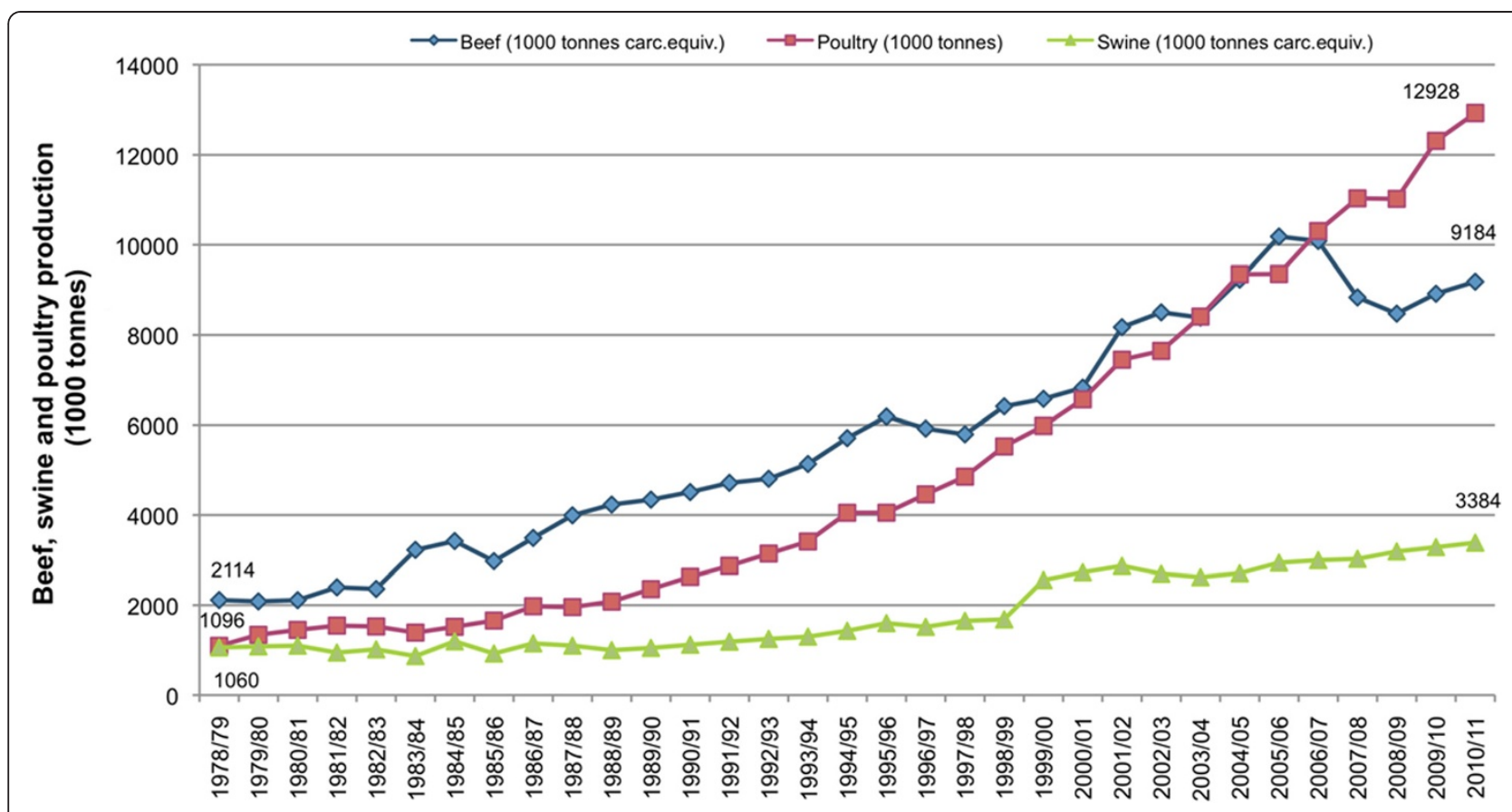

Figure 6 Evolution of meat production in Brazil from 1978/1979 to 2010/2011. Source: Conab database.

The need for science-based technologies, given the changing environment in response to climate change and to the evolving socioeconomic context, means that capacity building and strengthening in Brazilian agriculture will be of crucial importance in the coming decades. For this to be realized education should be significantly improved (around 50\% of rural workers have up to only four years of education; [21]. Knowledge and technology needs to be generated by organized (public and private) research and transferred to end users through the research system, which adapts technologies to the specific needs of the country and regions [22].

Brazil has an abundance of natural resources, which have been protected by the enormous land-saving effects provided by the productivity gains in Brazilian agriculture over the past decades. Weather conditions (rainfall, radiation, temperature) are conducive to at least one good crop per year, and in many grain-producing regions, they are favorable for two and sometimes even three crops per year. Soils generally do not have physical problems. Technologies delivered over the past 40 years have removed the constraints imposed by the poor acid soils of the Cerrado. Three examples of notable technologies that transformed Brazilian agriculture over the past four decades are discussed below.

\section{Biological nitrogen fixation}

Soybean varieties that require no nitrogen have been selected for use in Brazil [23], and yields of up to 6 tonnes/hectare have already been recorded [17]. Re- inoculating soybean crops with Bradyrhizobium species, even in soils with high Bradyrhizobium population, is a recommended practice [24].

There is still some debate on the actual amount of nitrogen that can be acquired from biological nitrogen fixation (BNF) in non-leguminous crops - associated BNF and, hence, on the overall BNF contribution to fertilizer$\mathrm{N}$ economy in these agricultural systems. For example, there is evidence that it is possible to obtain up to $50 \mathrm{~kg}$ of nitrogen per hectare per year from BNF in tropical pastures (using Brachiaria spp. and Panicum maximum); however, it is necessary to access such contributions in pastures under grazing conditions [25]. Positive results in replacing part of the requirement for nitrogen fertilizers with BNF have also been reported with other graminaceous plants, such as rice [26], and in bio-energy crops such as sugarcane [27].

\section{The development of the Brazilian savannah (Cerrado)}

The development of Brazilian Cerrado into agricultural land required a large portfolio of technologies, which have made the region one of the top grain and beef-producing regions in the world. Technology was the main driving force behind the development of agriculture in the Brazilian Cerrado, and included improving the soil to the standard required by agricultural use, producing new crop and pasture varieties, and improving the productivity of farm animals, mainly beef and dairy cattle.

The most important discoveries were related to improvement of soil fertility [28,29], BNF [23,26,27], new plant 
varieties and hybrids (see section on grain in Albuquerque and Silva [30]), use of no-tillage systems [31] and integrated crop and livestock systems [32]. The technologies applied were compatible with sustainable production, and took into account human and environmental needs. As discussed earlier, the increased yields have saved millions of hectares of native vegetation and tropical forests [18].

Some recently developed technologies are applicable to all crops, such as fertilization practices and no-tillage systems. Tailoring technologies to take into account regional variation, individual farms, and relative prices is required. Other technologies, however, are crop-specific, such as new crop varieties, or strategies to control diseases, pests, and weeds. Sustainable agriculture may be seen as a package of technologies, some of which fit several crops, and others which are specific to particular crops.

In 1970, grain production in the Cerrado was 8 million tonnes. By 2006, the production amounted to 48.2 million tonnes, a noteworthy annual growth rate of $5.2 \%$ (a six-fold increase) in 36 years (Table 3 ). Until 1980, grain production in the Cerrado followed an extensive margin. After that, production increased at a much faster rate than in the rest of Brazil, and the contribution of the Cerrado to total grain production increased from $35.4 \%$ in 1970 to $49.2 \%$ in 2006 (Table 3). In other words, the Cerrado biome in Brazil, which occupies roughly $25 \%$ of the country's territory, accounted for nearly $50 \%$ of grain production. This is certainly a notable feat, considering the acid, low-fertility nature of the soils in the region.

Apart from rice and edible beans, all other agricultural products analyzed in this section are being displaced into the Cerrado. Edible bean crops have remained stable but rice - which was used in the agricultural frontier expansion in the Cerrado in the 1970s and 1980s - is now concentrated in irrigated land in the southern part of Brazil or regions in the Cerrado not prone to extreme conditions. The most notable cases of crop expansion in the region are soybean and cotton.

In the period from 1970 to 1990, when the Cerrado was being opened up to agriculture, land was also being brought into agricultural production. Consequently, in the 1970-1980 period, the increased agricultural land area accounted for the largest share of increased production. In the after periods up to 2006, most of the increase in production was due to yield increases; in the 19702006 period, yield gains in the Cerrado accounted for $61.4 \%$ of agricultural production variation (Table 4 ).

The contribution of yield improvements to rice and beans production is notable (Table 5). Improvements in maize production throughout the past four decades and in coffee production in the past two decades were largely based on yield gains. The contribution of yield increases to cotton production varied considerably, and in the case of soybean, most of the production expansion was explained by area increase. It should be noted that recent (1996 to 2006) expansion of cropping areas in the Cerrado region (especially for soybean in the north and sugarcane in the south), is mainly a result of conversion of pasture to agricultural land.

Cerrado beef production totaled 0.83 million tons in 1975. Since then, it has had a noticeable annual growth rate of $4.1 \%$, attaining 2.89 million tons in 2006. Beef production from the Cerrado, as a percentage of Brazil's total production, exceeded $38 \%$ in all agricultural census years from 1975 to 2006, and was as high as 53.1\% (Table 6). Milk production from the Cerrado averaged 2.2 million liters in 1970, but steadily increased by $3.6 \%$ per year to reach 8.1 million liters in 2006. In the period 1975 to 2006, milk production in the Cerrado represented between $37 \%$ and $45 \%$ of total Brazilian milk production (Table 6).

The growth dynamics of the Cerrado's beef and milk production have been notable. From 1985, productivity increases have accounted for the entire expansion of beef production in the biome (Table 7). Martha et al. [18] investigated the contribution of the components of productivity in Brazil and reported that animal performance accounted for $65 \%$, whereas stocking rates were responsible for $35 \%$ of the gains.

Increased productivity accounted for $43 \%$ to $98 \%$ of the milk production increases over the 1975 to 1996

Table 3 Grain production (in million tonnes)* in the Cerrado region and in Brazil

\begin{tabular}{|c|c|c|c|c|c|c|c|c|c|}
\hline \multirow[t]{2}{*}{ Year } & \multicolumn{2}{|c|}{ Area in million hectares } & \multirow[b]{2}{*}{$\begin{array}{l}\text { Total production } \\
\text { in million tons* }\end{array}$} & \multicolumn{6}{|c|}{ Shares of Cerrado in Brazilian production (\% of the total) } \\
\hline & Cerrado & Brazil & & Rice & Edible beans & Maize & Soybean & Cotton & Coffee \\
\hline 1970 & 8.0 & 22.7 & 35.4 & 53.2 & 25.3 & 32.0 & 6.9 & 50.0 & 40.4 \\
\hline 1975 & 10.6 & 33.1 & 32.0 & 52.1 & 24.4 & 33.0 & 12.2 & 53.1 & 24.7 \\
\hline 1980 & 13.8 & 39.5 & 34.9 & 55.2 & 22.3 & 33.6 & 23.0 & 49.0 & 36.4 \\
\hline 1985 & 17.9 & 47.9 & 37.4 & 39.7 & 24.7 & 35.0 & 39.3 & 44.2 & 35.4 \\
\hline 1996 & 26.4 & 58.0 & 45.5 & 25.8 & 29.4 & 46,5 & 62.7 & 57.2 & 38.4 \\
\hline 2006 & 48.2 & 98,0 & 49.2 & 28.0 & 25.7 & 43.3 & 60.4 & 98.1 & 49.0 \\
\hline
\end{tabular}

* Includes rice, edible beans, soybean, maize, coffee, and also cotton. Source: Baldani and Baldani [26], using data from THE IBGE Agricultural Census. 
Table 4 Annual growth rates of production, area, and yield in the Cerrado, and yield contribution to growth

\begin{tabular}{lllll}
\hline Period & \multicolumn{2}{l}{ Growth,\% per year } & \multicolumn{2}{l}{$\begin{array}{l}\text { Yield share, } \\
\text { \% of growth }\end{array}$} \\
\cline { 2 - 4 } & Production & Area & Yield & \\
\hline 1970 to 2006 & 5.20 & 1.97 & 3.13 & 61.36 \\
1970 to 1975 & 5.73 & 3.16 & 2.57 & 44.86 \\
1975 to 1980 & 5.41 & 3.52 & 1.90 & 35.02 \\
1980 to 1985 & 5.30 & 2.59 & 2.71 & 51.04 \\
1985 to 1996 & 3.97 & -0.82 & 4.80 & 120.73 \\
1996 to 2006 & 5.62 & 3.06 & 2.56 & 45.49
\end{tabular}

Source: Alves [33], using data from THE IBGE Agricultural Census.

period (Table 7). In the past decade (1985 to 1996), yield accounted for $98 \%$ of the growth in production.

In summary, the significant productivity gains in animal production in the Cerrado were achieved as a result of the continual incorporation of technology. These productivity gains in beef and milk production provided land-saving effects that played an obvious pivotal role in making land available for crop expansion, thus minimizing pressure on natural resources.

\section{Integrated crop-livestock systems}

Integrated crop-livestock systems are an example of a resource-saving technology, and it has received much attention from researchers worldwide [32,34,35]. The main reported agronomic/environmental benefits of these systems are: improved chemical, physical and biological properties of the soil; reduction in disease, pest and weed outbreaks; and higher crop and animal productivity $[32,34,35]$. As a result of improved herbage quality (nutritive value and consumption), integrated crop-livestock systems can additionally contribute to lower methane emissions per unit of live weight gain for grazing animals.

As summarized by Vilela et al. [32], the adoption of these mixed systems in the Brazilian Cerrado region has been associated with: 1) a $15 \%$ increase in the soil organic matter content compared with the native Cerrado;

Table 5 Yield contribution to agricultural production growth in selected crops cultivated in the Brazilian Cerrado

\begin{tabular}{lllllll}
\hline Period & \multicolumn{1}{l}{ Crop } & \multicolumn{1}{l}{} \\
\cline { 2 - 7 } & Rice & Beans & Maize & Soybean & Coffee & Cotton \\
\hline 1970 to 2006 & 357.14 & 157.78 & 81.38 & 14.62 & 92.94 & 92.03 \\
1970 to 1975 & 8.12 & 511.59 & 83.19 & 11.98 & 45.49 & 102.96 \\
1975 to 1980 & 38.71 & 13.24 & 70.88 & 8.06 & -38.96 & 184.02 \\
1980 to 1985 & 18.52 & -324.48 & 59.18 & 7.39 & 94.07 & -12.58 \\
1985 to 1996 & 57.48 & 515.66 & 88.21 & 38.01 & 95.89 & 7.49 \\
1996 to 2006 & 718.39 & 159.87 & 81.63 & 19.17 & 83.50 & 44.44
\end{tabular}

Source: Alves [33], using data from THE IBGE Agricultural Census.
Table 6 Cerrado contribution to beef and milk production in Brazil

\begin{tabular}{lll}
\hline Year & \multicolumn{2}{l}{ Cerrado region share,\% of Brazilian production } \\
\cline { 2 - 3 } & Beef & Milk \\
\hline 1975 & 46.43 & 36.89 \\
1980 & 47.67 & 39.75 \\
1985 & 38.24 & 41.41 \\
1996 & 53.07 & 44.86 \\
2006 & 41.96 & 40.10 \\
\hline
\end{tabular}

Source: Alves [33], using data from THE IBGE Agricultural Census.

2) up to $90 \%$ increase in apparent phosphorus use efficiency in corn-soybean rotation; 3) soybean yield gains exceeding $10 \%$ using rotation with productive pastures compared with soybean in monoculture; and 4) up to three (cow-calf phase) and four-fold (rearing/finishing phase) increase in animal productivity for grazing cattle compared with traditional, extensive pastoral beef systems.

The potential economic benefits of these integrated crop-livestock systems may reflect economies of scope (reduced cost associated with producing multiple outputs) or the risk-reducing effects of diversification. The benefits of crop rotations (including pasture) may also include reduced yield variability and overall higher yields. Accurate measurement of interactions between crop and animal (pasture) components to allow for improved and unbiased decision-making is a key step to be pursued [36].

In Brazil, the high demand for capital in these mixed systems is perceived as a major constraint on their widespread adoption. High demand for capital also increases the financial risk of integrated crop-livestock systems, which needs to be weighed against potentially decreased production risks. The design of innovative financing mechanisms will be essential to foster and accelerate large-scale adoption of the integrated crop-livestock system technology [36].

\section{Some perspectives for Brazilian agriculture}

In this final section we would like to explore two key issues that will play a pivotal role in Brazilian agriculture

Table 7 Contribution of productivity gains to the growth of beef and milk production in the Cerrado

\begin{tabular}{lll}
\hline Year & \multicolumn{2}{l}{ Yield contribution,\% of production } \\
\cline { 2 - 3 } & Beef & Milk \\
\hline 1975 to 2006 & 103.28 & 49.03 \\
1975 to 1980 & 84.21 & 60.64 \\
1980 to 1985 & 95.69 & 42.87 \\
1985 to 1996 & 104.52 & 97.87 \\
1996 to 2006 & 114.96 & - \\
\hline
\end{tabular}

Source: Alves [33], using data from THE IBGE Agricultural Census. 
in the future. An important characteristic of Brazilian agriculture has been its ability to expand production with the involvement of farmers from small, medium and large farms. However, in Brazil, land accounts for about $20 \%$ of the total cost of production, therefore, land is not a good measure of farm size distribution, as other production factors have much greater influence on it.

One alternative measure is gross farm income. The 2006 Agricultural Census included in its database information about self-consumption on the farm and the share of production that is sold in the market, with both being used to estimate gross farm income (at market prices), and gross farm income being divided into classes of minimum wage in Brazil (at 2006 prices) (Table 8). The social class receiving the equivalent of less than one minimum wage contributed less than $2 \%$ of the agricultural value of production, and will not be considered in this discussion.

The first class was for farms with more than one and up to two minimum wage equivalents per month. This class accounted for $27 \%$ of the farms in the set and was denoted as the 'poor farms' class. The intermediate class represented medium-income farms, those that received from two up to ten minimum wage equivalents per month and represented roughly $50 \%$ of the farms analyzed. The third and final class represented the rich farms, those that received more than ten minimum wages per month.

In this normal distribution, family farms belonged to the first two classes. Most of their production was for the domestic market, but they also contributed to exports. The rich farm class produced for both foreign and domestic markets, and the amount for each market depended on relative prices: international compared with domestic prices. Most of the commercial farms belong to the rich class.

An interesting exercise is to explore gross income concentration as opposed to farm size (measured in hectares). We considered two groups of farms, those less than or equal to 100 hectares in size, and those greater than 100 hectares in size, and calculated the Gini coefficient for

\begin{tabular}{|c|c|c|c|}
\hline $\begin{array}{l}\text { Monthly minimum } \\
\text { wage }\end{array}$ & $\begin{array}{l}\text { Frequency } \\
\text { in number } \\
\text { of farms }\end{array}$ & $\begin{array}{l}\% \text { of farms } \\
\text { in each } \\
\text { category }\end{array}$ & $\begin{array}{l}\text { Monthly } \\
\text { gross } \\
\text { income } \\
\text { per farm }\end{array}$ \\
\hline (1 to 2$]$ & 570,480 & 27.32 & 1.43 \\
\hline (2 to 10$]$ & $1,012,038$ & 48.47 & 4.65 \\
\hline$>10$ & 505,621 & 24.21 & 49.93 \\
\hline Total & $2,088,139$ & 100.00 & 8.51 \\
\hline
\end{tabular}

Data from THE IBGE 2006 Agricultural Census (calculations by E. Alves). each group. For medium to small farms ( $\leq 100$ hectares), the Gini coefficient was 0.85 , while for larger farms, the corresponding result was 0.87 . As a Gini coefficient value of 1 expresses a state of maximum inequality (one group in this case would accrue all the income) it can be concluded that the income concentration measured by the Gini coefficient is not related to the agrarian structure (that is, the farm area in hectares) because concentration is high in both groups.

In a recent assessment, it was shown that in dynamic agricultural regions in the Cerrado, both GDP and the Human Development Index were higher than in less dynamic regions [37]. In fact, an incipient agricultural region such as the Brazilian northeast contained most (about $60 \%$ ) of the poor farms indicated in Table 8. The remaining $40 \%$ of the poor farms were evenly distributed across the other regions (north, southeast, south and center-west) of the country (see additional details in Alves and Rocha [14]). The intermediate and rich farms were present in all five regions, with a slightly higher concentration of rich farms in the midwestern region. Hence, public policies have been correctly targeted to stimulate income growth in family farms, both for their benefit and for that of the domestic food market.

Regarding the technology issue, some key technologies that will eventually be supported in the near future are: new varieties and cultivars (adapted to non-native ecosystems, with a higher yield in a given environmental set of conditions, resistance and/or tolerance to biotic and abiotic stresses, incorporation of biotechnology and nanotechnology tools); new inputs (machinery and equipment, fertilizers and agrochemicals); and new agricultural practices and innovative production systems (providing greater efficiency in water and nutrient use, and accommodation of multiple crop cycles in a year). Obviously, the research system and the extension service must receive adequate financial support in order to sustain continuous gains in agricultural yields in farms.

Thus a main future challenge for research, given the ample array of stakeholder pressure and funding possibilities, is clearly and objectively identifying the sequence of relevant problems that shall be solved by research in order to increase welfare in society [8]. Additionally, gains in productivity benefit the whole society, but poor families in rural areas and in cities receive the greatest share of these benefits, because the greatest share of the poor's income is spent with food acquisition. Thus, reducing the price of food works as income transfer to the poor without the need for reallocation of income within society.

For this reason, agricultural policies need to be designed to support research efforts that stimulate growth in productivity. Given current and future societal demand, this growth in productivity will need to focus 
on the development and/or adaptation of resource-saving (for example, land, water, and nutrients) technologies that protect the environment and use resources more efficiently.

It is desirable that these novel technologies should also contribute to mitigate carbon emissions under a green growth strategy. Agricultural policies in Brazil already promote the importance of expanding the use of low-carbon agricultural technologies. In the 2011-2012 Agricultural and Livestock Plan of the Ministry of Agriculture, Livestock and Food Supply, the Low Carbon Agriculture (ABC) credit line has R $\$ 3.15$ billion (approximately USD $\$ 1.75$ billion) allocated to it, with annual interest rates of $5.5 \%$.

In accordance with the Law on Climate Change that was approved in December 2009, it is estimated that the agricultural sector (through recovery of low-productive pastures, and stimulus to increase adoption of integrated crop-livestock systems, BNF usage, and high-quality no-till planting) and the biofuel sector will be able to reduce the greenhouse gas emissions related to the baseline scenario by 226 Mega tonnes of CO2 equivalent by 2020 . This implies that the agricultural sector alone may be responsible for $21.5 \%$ of the mitigation actions proposed by the Brazilian government. Pasture intensification, by avoiding further deforestation, freeing up large areas of pasture to accommodate crop area expansion, and directly or indirectly reducing greenhouse gas emissions, will play a decisive role in this process [18].

\section{Conclusion}

The development of Brazilian agriculture was greatly boosted by the forced-draft industrialization policy taking place in the country between 1960 and 1985. In this process, a large share of the country's geographic area, the Cerrado, which was once thought to be of limited value for agricultural production, proved to be a productive region when scientific knowledge and sound policies were used by entrepreneur farmers. The experience of the agricultural transformation in Brazil is proof that it is possible to have an efficient and competitive agriculture in the tropics.

The development of Brazilian agriculture was predominantly based on productivity gains. Again, science played a pivotal role in the development of land-saving technologies. There are clear opportunities to advance in this path of sustainability while at the same time expanding the production of food, biofuel, and fiber. Intensifying pastoral systems will be of central importance in such a policy.

Agricultural technologies in accordance with a green growth strategy, consistent with environmental protection in the long term, using natural resources within their carrying capacity, while providing acceptable living standards and poverty reduction [38]) are already available and are increasingly being adopted by Brazilian farmers. However, the design of innovative financing mechanisms will be essential to foster and speed a large-scale adoption of technology [36].

Finally, from a global perspective, the increase in agricultural exports in Brazil reflects the important contribution of the country to reduce world hunger and macroeconomic (inflationary) pressures, and to stabilize prices in agricultural markets. This ability to expand its agricultural production in a sustainable, scientific-based path will inevitably strengthen Brazil's role in world markets in the near future.

\section{Abbreviations}

BNF: Biological nitrogen fixation; GDP: Gross domestic product; TFP: Total factor productivity.

\section{Competing interests}

The authors declare that they have no competing interests.

\section{Author details}

${ }^{1}$ Brazilian Agricultural Research Corporation (Embrapa), Brasília, Brazil. ${ }^{2}$ Embrapa Studies and Training, National Council for Scientific and Technological Development (CNPq) fellow, Brasília, Brazil. ${ }^{3}$ Embrapa Studies and Training, Brasília, Brazil. "President's Office, Brasília, Brazil.

\section{Authors' contributions}

PAAP and EA conceived and designed the study. GBMJ and EA acquired an analyzed data. PAAP, GBMJ, CAMS and EA drafted the manuscript. The authors read and approved the final manuscript.

Received: 23 January 2012 Accepted: 15 March 2012 Published: 19 April 2012

\section{References}

1. HLPE: Price volatility and food security. A report by the High Level Panel of Experts on Food Security and Nutrition. Rome: Committee on World Food Security; 2011.

2. OECD/FAO: Agricultural Outlook 2009-2018. Paris: OECD; 2009.

3. USDA: Agricultural Projections to 2019. Washington: USDA; 2010.

4. EIU (Economist Intelligence Unit): Agriculture in high-growth markets: securing global food supplies. London: Economist Intelligence Unit; 2012.

5. UNDP (United Nations Population Division): World population prospects The 2010 Revision: Highlights and tables. UNDP: New York; 2011.

6. FAO (Food and Agriculture Organization): Land resource potential and constraints at regional and country levels (World Soil Resources Report 90). Rome: FAO; 2000.

7. WRI (World Resource Institute): World resources 2008: the roots of resilience growing the wealth of the poor. Washington: WRl; 2008.

8. Martha Jr GB, Contini E, Alves, E: Embrapa: its origins and change. In: The regional impact of national policies: the case of Brazil. Edited by Baer W. Northampton: Edward Elgar Publishers; 2012 (in press).

9. Baer W: The Brazilian economy. 6th edition. Boulder: Lynne Rienner Publishers; 2008

10. Thorp R: Progress, poverty and exclusion: an economic history of Latin America in the 20th century. Washington: Inter-American Development Bank; 1998.

11. Gremaud A, Vasconcellos MAS, Toneto R Jr: Contemporary Brazilian economy. 5th edition. São Paulo: Editora Atlas; 2004

12. Alves E, Pastore AC: Import substitution and implicit taxation of agriculture in Brazil. Am J Agr Econ 1978, 60:865-871.

13. Dias GL, Amaral CM: Structural changes in Brazilian Agricultural, 19802008. In: Brasil: uma década em transição. Organized by Baumann R. Rio de Janeiro: Cepal/Campus; 2000.

14. Alves E, Rocha DP: Is it possible to spare time? In: Agricultura brasileira: desempenho, desafios e perspectivas. Organized by Gasques JG, Vieira Filho JER, Navarro Z. Brasília: IPEA; 2010: 275-290.

15. Alves E: Embrapa: a successful case of institutional innovation. Rev Polít Agrc 2010, 19(special issue):64-72.

16. Alves E, Sousa GS, Brandão ASP: Why the food basket prices has dropped? Rev Polít Agrc 2010, 19:14-20. 
17. Martha Jr GB, Alves E, Contini E, Ramos SY: The development of Brazilian agriculture and future challenges. Rev Polit Agríc 2010, 19 (special issue):91-104

18. Martha Jr GB, Alves E, Contini E: Land-saving approaches and beef production growth in Brazil. Agric Syst; in press.

19. Gasques JG, Bastos ET, Bacchi MRP, Valdes C: Total factor productivity and transformations in Brazilian agriculture: analysis of the Agricultural Censuses data. In: Agricultura brasileira: desempenho, desafios e perspectivas Organized by Gasques JG, Vieira Filho, JER, Navarro Z. Brasília: IPEA, 2010.

20. Contini E, Gasques JG, Alves E, Bastos ET: Dynamism of Brazilian agriculture. Rev Polit Agríc 2010, 19(special issue):42-63.

21. Freitas CA, Bacha CJC, Fossatti DM: Evaluation of the agricultural sector development in Brazil: period 1970 to 2000. Econ Soc 2007, 16:111-124.

22. Alves E: Mobilizing political support for the Brazilian agricultural research system. In Policy for agricultural research. Edited by Ruttan WW, Pray CE. Boulder: Westview Press; 1985.

23. Dobereiner J: Biological nitrogen fixation in the tropics: social and economic contributions. Soil Biol Biochem 1997, 29:771-774.

24. Hungria M, Franchini JC, Campo RJ, Crispino CC, Moraes J, Sibaldelli RNR, Mendes IC, Arihara J: Nitrogen nutrition of soybean in Brazil: contribution of biological N2 fixation and nitrogen fertilizer to grain yield. Can J Plant Sci 2006, 86:927-939.

25. Boddey RM, Sá JCM, Alves BJR, Urquiaga S: The contribution of biological nitrogen fixation for sustainable agricultural systems in the tropics. Soil Biol Biochem 1997, 29:787-799.

26. Baldani JL, Baldani VLD: History of biological nitrogen fixation research in graminaceous plants: special emphasis on the Brazilian experience. An Acad Bras Ciênc 2005, 77:549-579.

27. Dobereiner J, Baldani VLD, Reis VM: The role of biological nitrogen fixation to bio-energy programmes in the tropics. In Transition to global sustainability: the contribution of Brazilian science. Edited by Rocha-Miranda CE. Rio de Janeiro: Academia Brasileira de Ciências; 2000.

28. Goedert W: Cerrados soils: technologies and management strategies. Planaltina: Embrapa-CPAC/Nobel; 1987.

29. Sousa DMG, Lobato E: Cerrado: soil correction and fertilization. Brasília: Embrapa Informação Tecnológica; 2004.

30. Albuquerque, A.C.S.; Silva, A.G. (Ed.): Tropical agriculture: four decades of technological, institutional and political innovation, vol. 1. Brasília: Embrapa Informação Tecnológica, 2008. 1337p.

31. Denardin JE, Kochhann RA, Bacaltchuk B, Sattler A, Denardin NA, Faganello A, Wietholter S: Sistema de plantio direto: fator de potencialidade da agricultura tropical brasileira [No-till planting: factor to potentialize Brazilian tropical agriculture]. In Tropical agriculture: four decades of technological, institutional and political innovation, vol.1. Edited by Albuquerque ACS, Silva AG. Brasília: Embrapa Informação Tecnológica; 2008.

32. Vilela L, Martha Jr GB, Macedo MCM, Marchão RL, Guimarães R Jr, Pulrolnik K, Maciel GA: Integrated crop-livestock systems in the Cerrado region. Pesquisa Agropecuária Brasileira 2011, 46:1127-1138.

33. Alves E: Development of Brazilian agriculture. Brasília: Embrapa, Internal Report, President's Office; 2011.

34. Sulc RM, Tracy BF: Integrated crop-livestock systems in the U.S. corn belt. Agron J 2007, 99:335-345.

35. Herrero M, Thornton PK, Notenbaert AM, Wood S, Msangi S, Freeman HA Bossio D, Dixon J, Peters M, van de Steeg J, Lynam J, Parthasarathy Rao P, Macmillan S, Gerard B, McDermott J, Seré C, Rosegrant M: Smart investments in sustainable food production: revisiting mixed crop-livestock systems. Science 2010, 327:822-825.

36. Martha Jr GB, Alves $E$, Contini E: Economic dimension of integrated crop-livestock systems. Pesquisa Agropecuária Brasileira 2011, 46:11171126.

37. Mueller CC, Martha GB Jr: Agriculture and contemporary socioeconomic development in the Cerrado. In Savanas: desafios estratégias para o equilibrio entre sociedade, agronegócio e recursos naturais. Edited by Faleiro FG, Farias Neto AL. Planaltina: Embrapa Cerrados; 2008:35-99.

38. OECD: Food and Agriculture, OECD Green studies. Paris: OECD Publishing; 2011.

39. Martha Jr GB: Factors of growth, yield potentials and economic yield gaps in Brazilian maize and soybean production. Brasília: Embrapa Studies and Training, Internal Report, Strategic Studies Team; 2012. doi:10.1186/2048-7010-1-4

Cite this article as: Pereira et al: The development of Brazilian agriculture: future technological challenges and opportunities. Agriculture \& Food Security 2012 1:4.

\section{Submit your next manuscript to BioMed Central and take full advantage of:}

- Convenient online submission

- Thorough peer review

- No space constraints or color figure charges

- Immediate publication on acceptance

- Inclusion in PubMed, CAS, Scopus and Google Scholar

- Research which is freely available for redistribution

Submit your manuscript at www.biomedcentral.com/submit 